\title{
Evoked otoacoustic emissions in workers exposed to noise: A review
}

\author{
Patrícia Arruda de Souza Alcarás', Débora Lüders', Denise Maria Vaz Romano França', Regina Maria Klas², \\ Adriana Bender Moreira de Lacerda ${ }^{3}$, Cláudia Giglio de Oliveira Gonçalves ${ }^{3}$.
}

1) Master. Fonoaudiology - Teacher.

2) Master. Fonoaudiology.

3) Doctor. Fonoaudiology - Teacher.

Institution: Trabalho realizado no Programa de Mestrado e Doutorado em Distúrbios da Comunicação Humana, Universidade Tuiuti do Paraná - UTP. Curitiba / PR - Brazil.

Mailing address: Patrícia Arruda de Souza Alcarás - Rua Manoel Eugênio, 529 - Cidade Universitária - Presidente Prudente / SP - Brazil - Zip code: 19050-300 - E-mail: patricialcaras@hotmail.com

Article received in March 2, 2012. Article approved in May 27, 2012.

\section{SUMMARY}

Introduction: The otoacoustic emissions test is an essential tool in the evaluation of auditory function, since it allows the early detection of cochlear damage of occupational origin.

Objective: To present a review of the literature and analyze the effectiveness of the clinical application of the otoacoustic emissions test in workers exposed to noise.

Methods: A bibliographical search covering a period of 10 years was performed in the Virtual Health Library including published articles in national and international journals indexed in the internationally recognized databases for the health sciences, LILACS, SCIELO, and MEDLINE, using the terms "otoacoustic emissions" and "occupational exposure." The type of published article (national/international), the type and intensity of the stimulus most commonly used for the evoked otoacoustic emissions, the gender and age of the subjects, and the conclusions from the retrospective studies were all taken into consideration.

Results and Conclusions: A total of 19 articles were analyzed, 7 national and 12 international, covering subjects from 17 to 77 years of age, mostly men. The type of stimulus most commonly used for the evoked otoacoustic emissions was the distortion method (12). Through this review, we have concluded that testing of evoked otoacoustic emissions in workers exposed to noise is an important tool in the early diagnosis of noise-induced cochlear hearing disorders.

Keywords: occupational health; hearing; electrophysiology; noise effects; occupational exposure.

\section{INTRODUCTION}

Hearing is crucial in the communication process, and any change in auditory perception can lead to problems in communication and socialization of human beings with their peers $(1,2)$.

Exposure to loud noise is an occupational health risk factor, causing general, and auditory disturbances $(3,4)$. In the auditory system, noise will affect mainly the outer hair cells in the cochlea.

Current knowledge of the physiology of hearing aids, particularly in the functioning of the cochlea, allows for insight regarding studies of noise-induced hearing loss (NIHL).

It has been reported (5) that noise can affect cochlear function through 7 possible mechanisms: 1 . by direct mechanical injury, 2 . by excess glutamate in the synapses of inner hair cells, 3 . by over-stimulation of $N$ methyl-D-aspartame receptors that would lead to the release of nitric oxide, 4 . by free radicals of oxygen atoms, 5 . by a reduction of magnesium that would alter intracellular activity, 6 . by an increase of intracellular calcium, and 7 . by protein damage.

NIHL is irreversible and progressive sensorineural cochlear damage. In the early stages of NIHL, the individual may have tinnitus and a fleeting feeling of auditory plenitude, but the hearing loss cannot be identified in an audiogram. However, with continued exposure to loud noise over several years, there will be hearing loss that can be described in an audiogram, initiating then a permanent decline in hearing (6).

It has also been reported (7) that cell damage by noise can be described in 3 stages, in accordance with exposure time: 
1. onset, the death of hair cells with formation of scabs, which is not distinguishable by conventional audiometry; 2 . after several years of exposure, damage in the first third of the cochlea, or $10 \mathrm{~mm}$ from the cochlear base, which is a more sensitive area owing to metabolic, vascular, and anatomical factors, with detectable changes in audiometric pure tone thresholds of 3-6 kHz; 3. after decades of exposure, injuries of a more extensive range in the cochlea, affecting the mid and low frequencies.

Legally, the evaluation of patients with NIHL occurs through the use of audiometric tests (8). Currently, other objective tests are recommended for early diagnosis of NIHL, as in the case of evoked otoacoustic emissions (EOAE) $(9,10,11,12)$.

EOAE testing was introduced at the end of the 1970 s (13), and reduction in the amplitude of EOAE intensity response in patients with NIHL compared to the unexposed group was demonstrated.

Recent research shows that the EOAE test has become an essential tool in the evaluation of auditory function because it allows early detection of cochlear damage resulting from occupational noise (14).

The aim of this study was to analyze the recent scientific literature on the clinical application EOAE tests in workers exposed to noise.

\section{Methods}

The universe of analysis chosen for the literature review included scientific publications in national and international journals that were indexed in 3 internationally recognized databases for the health sciences: LILACS, SciELO, and Medline. A search was performed in the Virtual Health Library, covering a period of 10 years, using the terms "otoacoustic emissions" and "occupational exposure."

A survey of the publications was initially performed by reading abstracts in the BIREME virtual library (www.bireme.br), and when the abstract served the interests of this study, the full text of the article was requested for analysis.

The indexed periodicals surveyed in the databases included for this review were national and international scientific publications published in Portuguese or English between 2000 and 2010.

There were 19 papers selected for analysis, 7 national and 12 international. Only 1 study was excluded because its subject of research was animals exposed to broadband noise.

\section{REVIEW}

After selection and full analysis of the publications, each article was classified according to whether it was nationally or internationally published, and the articles were indexed by 5 categories: database, article title, author, year, and country of publication.

Next, we analyzed the criteria used by the authors of each article, taking into account the following variables: number of participants, age (given by the variance or mean age), and gender.

Finally, analyses were made of the parameters used in the investigation of the EOAE tests, classifying them by stimulus intensity and type of test: transient evoked, distortion product, or both.

Chart 1 presents the studies classified according to their origin (national/international), database, title, author, year, and country of publication.

Table 1 presents the criteria of the research, taking into account the age (given by the variance or mean age), gender, and number of subjects.

Table 2 shows the analysis of parameters used to investigate the OAEs according to the type of test: transient evoked (TEOAE), distortion product (DPOAE)(11;57.89\%), or both $(8,42.11 \%)$, and the intensity of the stimulus.

\section{RESULTS}

The goal of this review was to analyze the scientific literature on the clinical application of EOAE tests for workers exposed to noise.

In referring to the origin of publications, there were more articles found in international journals than in national journals (Chart 1).

The results the analysis suggest that EOAE testing is a valuable tool for occupational health research and early diagnosis of NIHL in various professions.

The occupational categories included were: musicians $(15,16,17)$, fishermen (18), farmers (12), construction workers $(19,20)$, military personnel (21), textile industry workers (22), workers in various industrial activities $(23,24,25,26,27)$, university employees exposed 
Chart I. Analysis of scientific articles regarding otoacoustic emissions in workers exposed to occupational noise based on database, article title, author, and year/country.

\begin{tabular}{|c|c|c|c|c|}
\hline$\overline{\mathrm{T}}$ & Database & Article Title & Author & Year/Country \\
\hline \multicolumn{5}{|c|}{ National } \\
\hline I & LILACS & Estudo da audição de músicos de rockandroll & Maia and Russo ( 16 ) & 2008/Brasil \\
\hline 2 & LILACS & $\begin{array}{l}\text { Exposição ao ruído ocupacional: alteração no exame de emissões } \\
\text { otoacústicas }\end{array}$ & Marquesand Costa(4) & 2006/Brasil \\
\hline 3 & LILACS & $\begin{array}{l}\text { Emissões otoacústicas - produto de distorção emindivíduos } \\
\text { expostos ao chumbo e ao ruído }\end{array}$ & Alvarenga etal.(23) & 2003/Brasil \\
\hline 4 & LILACS & $\begin{array}{l}\text { Avaliação Audiológica e de emissões otoacústicas em indivíduos } \\
\text { expostos a ruído e praguicida }\end{array}$ & Guida etal. (12) & 2009/Brasil \\
\hline 5 & LILACS & Alterações auditivas da exposição ocupacional em músicos & Amorinetal. ( 15$)$ & 2008/Brasil \\
\hline 6 & LILACS & $\begin{array}{l}\text { Emissões otoacústicas-Produto de distorção: Estudo de diferentes } \\
\text { relações de níveis sonoros no teste em indivíduos come sem } \\
\text { perdas auditivas }\end{array}$ & FioriniandParrado-Moran(22) & 2005/Brasil \\
\hline 7 & LILACS & $\begin{array}{l}\text { Aplicações clínicas das emissões otoacústicas: produto de distorção } \\
\text { emindivíduos com perda auditiva induzida por ruído ocupacional }\end{array}$ & Parrado-MoranandFiorini(3l) & ) 2003/Brasil \\
\hline \multicolumn{5}{|c|}{ International } \\
\hline 8 & Medline & $\begin{array}{l}\text { Audiological findingsamong workers from Brazilian small-scale } \\
\text { fisheries }\end{array}$ & Paini et al. ( 18$)$ & 2009/USA \\
\hline 9 & Medline & \multicolumn{2}{|c|}{$\begin{array}{l}\text { Audiological findings in workers exposed to styrene alone or in concert with noise } \\
\text { (24) 2006/England }\end{array}$} & Johnsonetal. \\
\hline 10 & Medline & Distortion product otoacoustic emissions in an industrial setting & Korres etal. (25) & 2009/England \\
\hline $\mid \mathrm{I}$ & Medline & $\begin{array}{l}\text { Effect of exposure to a mixture of solvents and noise on hearing and } \\
\text { balance inaircraft maintenance workers }\end{array}$ & Prasher etal.(28) & 2005/England \\
\hline 12 & Medline & $\begin{array}{l}\text { Effectiveness of hearing protector devices in impulse noise verified } \\
\text { with transiently evokedand distortion product otoacoustic emissions }\end{array}$ & Bockstaeletal. (2I) & 2008/USA \\
\hline 13 & Medline & $\begin{array}{l}\text { Low-level otoacoustic emissions may predictsusceptibility to noise- } \\
\text { induced hearing loss }\end{array}$ & Lapsley Milleretal.(29) & 2006/USA \\
\hline 14 & Medline & Music exposure and audiological findings in Brazilian disc jockeys & Santos et al. (17) & 2007/USA \\
\hline 15 & Medline & $\begin{array}{l}\text { Otoacoustic emission sensitivity to low levels of noise-induced } \\
\text { hearing loss }\end{array}$ & Sisto et al. (26) & 2007/USA \\
\hline 16 & Medline & $\begin{array}{l}\text { Predictions of hearing threshold levels and Distortion product } \\
\text { otoacoustic emissions among noise exposed young adults }\end{array}$ & Seixas et al. (19) & 2004/England \\
\hline 17 & Medline & $\begin{array}{l}\text { Prospective noise induced changes to hearing among construction } \\
\text { industryapprentices }\end{array}$ & Seixas et al. (20) & 2005/England \\
\hline 18 & Medline & $\begin{array}{l}\text { Susceptibility to tinnitus revealed at } 2 \mathrm{kH} \text { z range by bilateral lower } \\
\text { DPOAEs in normal hearing subjects with noise exposure }\end{array}$ & $\begin{array}{l}\text { Job, Raynal, and } \\
\text { Kossowski (30) }\end{array}$ & $\begin{array}{l}2007 / \\
\text { Switzerland }\end{array}$ \\
\hline 19 & Medline & $\begin{array}{l}\text { The evaluation of noise-induced hearing loss with distortion } \\
\text { product otoacoustic emissions }\end{array}$ & Balatsouras $(27)$ & 2004/Poland \\
\hline
\end{tabular}

Legend: DPOAE: distortion product otoacoustic emissions

to occupational noise (4), carpenters (4), aviation employees (28), mariners (29), aviators (30), and workers exposed to noise (31) (Table 1).

Regarding the combined exposure to noise and environmental contaminants (solvents, asphyxiants, metals, and pesticides) (31), it was noted that there is controversy on this subject. While some authors offered significant evidence of effects on EOAE results in workers exposed simultaneously to noise and chemicals compared to workers exposed only to noise $(12,24,28)$, other authors did not agree (23).

For all studies (Table 1), the total number of 
Table I. Analysis of criteria used in the studies according to the number of participants, age group, and gender

\begin{tabular}{|c|c|c|c|c|c|}
\hline Article & Database & Title & $\begin{array}{l}\text { Number } \\
\text { of Subjec }\end{array}$ & $\begin{array}{l}\text { Age Group } \\
\text { ets }\end{array}$ & Gender \\
\hline I & LILACS & Estudo da audição de músicos de rock androll & 23 & $21-38$ & $\begin{array}{l}19 M \\
4 F\end{array}$ \\
\hline 2 & LILACS & $\begin{array}{l}\text { Exposição ao ruído ocupacional: alteração no exame de emissões } \\
\text { otoacústicas }\end{array}$ & 74 & Notspecified & $74 M$ \\
\hline 3 & LILACS & $\begin{array}{l}\text { Emissões otoacústicas - produto de distorção em indivíduos expostos } \\
\text { ao chumbo e ao ruído }\end{array}$ & 66 & $34-40$ & $\begin{array}{l}\text { Not } \\
\text { specified }\end{array}$ \\
\hline 4 & LILACS & $\begin{array}{l}\text { Avaliação Audiológica e de emissões otoacústicas emindivíduos } \\
\text { expostos a ruído e praguicida }\end{array}$ & 51 & $24-57$ & $5 \mid \mathrm{M}$ \\
\hline 5 & LILACS & Alterações auditivas da exposição ocupacional em músicos & 30 & $18-37$ & $\begin{array}{l}27 M \\
3 F\end{array}$ \\
\hline 6 & LILACS & $\begin{array}{l}\text { Emissões otoacústicas - Produto de distorção: Estudo de diferentes } \\
\text { relações de níveis sonoros no teste em indivíduos come sem perdas } \\
\text { auditivas }\end{array}$ & $\begin{array}{l}\mathrm{G} 1=8 \mathrm{C} \\
\mathrm{G} 2=89\end{array}$ & $\begin{array}{l}014-46 \\
920-60\end{array}$ & $\begin{array}{l}66 M \\
14 F \\
66 M \\
4 F\end{array}$ \\
\hline 7 & LILACS & $\begin{array}{l}\text { Aplicações clínicas das emissões otoacústicas: produto de distroção em } \\
\text { indivíduos com perda auditiva induzida por ruído ocupacional }\end{array}$ & 89 & $20-60$ & $\begin{array}{l}64 \mathrm{M} \\
4 \mathrm{~F}\end{array}$ \\
\hline 8 & Medline & Audiological findings among workersfrom Brazilian small-scale fisheries & $|4|$ & |8-77 & $14 \mid \mathrm{M}$ \\
\hline 9 & Medline & $\begin{array}{l}\text { Audiological findings in workers exposed to styrene alone or in concert } \\
\text { with noise }\end{array}$ & 313 & $20-65$ & $\begin{array}{l}278 \mathrm{M} \\
35 \mathrm{~F}\end{array}$ \\
\hline 10 & Medline & Distortion product otoacoustic emissions in an industrial setting & 139 & $24-54$ & $\begin{array}{l}86 M \\
53 \mathrm{~F}\end{array}$ \\
\hline । & Medline & $\begin{array}{l}\text { Effect of exposure to a mixture of solvents and noise on hearing and } \\
\text { balance inaircraft maintenance workers }\end{array}$ & $\begin{array}{l}\mathrm{G} 1=172 \\
\mathrm{G} 2=15 \\
\mathrm{G} 3=13 \\
\mathrm{G} 4=39\end{array}$ & $\begin{aligned} 4 \mathrm{G} I & =47.4 \mathrm{avg} . \\
3 \mathrm{G} 2 & =53.3 \mathrm{avg} . \\
\mathrm{G} 3 & =49.6 \mathrm{avg} . \\
\mathrm{G} 4 & =47.6 \mathrm{avg} .\end{aligned}$ & $\begin{array}{l}\text { Not } \\
\text { specified }\end{array}$ \\
\hline 12 & Medline & $\begin{array}{l}\text { Effectiveness of hearing protector devices in impulse noise verified with } \\
\text { transiently evoked and distortion product otoacousticemissions }\end{array}$ & 55 & 19-48 & $55 M$ \\
\hline 13 & Medline & $\begin{array}{l}\text { Low-level otoacoustic emissions may predictsusceptibility } \\
\text { to noise-induced hearing loss }\end{array}$ & $\begin{array}{l}\mathrm{G} 1=338 \\
\mathrm{G} 2=28\end{array}$ & $\begin{array}{l}818-46 \\
20-53\end{array}$ & $\begin{array}{l}35 F \\
303 M \\
8 F \\
20 M\end{array}$ \\
\hline 14 & Medline & Music exposure and audiological findings in Brazilian disc jockeys (D/s) & 30 & 17-39 & $30 M$ \\
\hline 15 & Medline & Otoacoustic emission sensitivity to low levels of noise-induced hearing loss & 217 & $18-35$ & $\begin{array}{l}\text { Not } \\
\text { specified }\end{array}$ \\
\hline 16 & Medline & $\begin{array}{l}\text { Predictors of hearingthreshold levels and distortion product } \\
\text { otoacoustic emissions among noise exposed young adults }\end{array}$ & 436 & 17-57 & $\begin{array}{l}367 M \\
69 F\end{array}$ \\
\hline 17 & Medline & $\begin{array}{l}\text { Prospective noise induced changes to hearing among construction } \\
\text { industryapprentices }\end{array}$ & 328 & $27.5 \mathrm{avg}$ & $\begin{array}{l}272 M \\
56 F\end{array}$ \\
\hline 18 & Medline & $\begin{array}{l}\text { Susceptibility to tinnitus revealedat } 2 \mathrm{kHz} \text { range by bilateral lower } \\
\text { DPOAEs in normal hearing subjects with noise exposure }\end{array}$ & 316 & $25-35$ & $\begin{array}{l}306 \mathrm{M} \\
10 \mathrm{~F}\end{array}$ \\
\hline 19 & Medline & $\begin{array}{l}\text { The evaluation of noise-induced hearing loss with distortion } \\
\text { product otoacousticemissions }\end{array}$ & 34 & $29-54$ & $\begin{array}{l}22 \mathrm{M} \\
12 \mathrm{~F}\end{array}$ \\
\hline
\end{tabular}

Legend: M, male; F, female; G I , 2, 3,4, groups; avg., average; DPOAEs, distortion product otoacoustic emissions. 
Table 2. Analysis of scientific articles in relation to the research parameters used.

\begin{tabular}{|c|c|c|c|c|c|}
\hline \multirow{3}{*}{$\frac{\text { Article }}{\text { I }}$} & \multirow{3}{*}{$\begin{array}{l}\text { Database } \\
\text { LILACS }\end{array}$} & \multirow{3}{*}{$\begin{array}{l}\text { Author } \\
\text { Maia and Russo (16) }\end{array}$} & \multirow{3}{*}{$\begin{array}{l}\text { Year/Country } \\
\text { 2008/Brazil }\end{array}$} & \multicolumn{2}{|c|}{ Type of OAE Stimulus Intensity } \\
\hline & & & & TEOAE & $80 \mathrm{~dB} S P L$ \\
\hline & & & & DPOAE & $L I=65 \mathrm{~dB} S P L, L 2=55 \mathrm{~dB} S P L$ \\
\hline 2 & LILACS & Marques and Costa (4) & 2006/Brazil & DPOAE & $L I$ and $L 2$ intensity not specified \\
\hline 3 & LILACS & Alvarengaetal.(23) & 2003/Brazil & DPOAE & $L I=70 \mathrm{~dB}, \mathrm{~L} 2=70 \mathrm{~dB}$ \\
\hline 4 & LILACS & Guida etal.(12) & 2009/Brazil & DPOAE & $\mathrm{LI}=65 \mathrm{~dB} S P L, L 2=55 \mathrm{~dB} S P L$ \\
\hline \multirow[t]{2}{*}{5} & LILACS & Amorinetal.(15) & 2008/Brazil & TEOAE & 79-83 dB SPL \\
\hline & & & & DPOAE & $\mathrm{LI}=65 \mathrm{~dB} \mathrm{SPL}, \mathrm{L} 2=55 \mathrm{~dB} \mathrm{SPL}$ \\
\hline 6 & LILACS & \multicolumn{2}{|c|}{ FioriniandParrado-Moran(22) 2005/Brazil } & DPOAE & $\begin{array}{l}L I \text { and } L 2=70 \mathrm{~dB} S P L \\
L I=65 \mathrm{~dB} S P L, L 2=55 \mathrm{~dB} \mathrm{SPL}\end{array}$ \\
\hline 7 & LILACS & \multicolumn{2}{|c|}{ Parrado-MoranandFiorini(3 I)2003/Brazil } & DPOAE & $L I=65 d B S P L, L 2=55 d B S P L$ \\
\hline 8 & Medline & Painietal.(|8) & 2009/USA & & \\
\hline 9 & Medline & Johnson et al. (24) & 2006/England & DPOAE & $L 2=10 \mathrm{~dB}$ below $\mathrm{LI}$, intensity not specified \\
\hline 10 & Medline & Korres et al. (25) & 2009/England & DPOAE & $\mathrm{fl}=60 \mathrm{~dB} S P L, f 2=45 \mathrm{~dB} \mathrm{SPL}$ \\
\hline \multirow[t]{2}{*}{ I I } & Medline & Prasher et al. (28) & 2005/England & TEOAE & $80 \mathrm{~dB} S P L$ \\
\hline & & & & DPOAE & $\mathrm{LI}=5 \mathrm{~dB} S P L, L 2=55 \mathrm{~dB} \mathrm{SPL}$ \\
\hline \multirow[t]{2}{*}{12} & Medline & Bockstaeletal. (2I) & 2008/USA & TEOAE & $86 \mathrm{~dB} S P L$ \\
\hline & & & & DPOAE & $L I=75 \mathrm{~dB} S P L, L 2=70 \mathrm{~dB} S P L$ \\
\hline \multirow[t]{2}{*}{13} & Medline & Lapsley Milleretal.(29) & 2006/USA & TEOAE & $74 \mathrm{~dB}$ pSPL click \\
\hline & & & & DPOAE & $\begin{array}{l}L I=57 \mathrm{~dB} S P L, L 2=45 \mathrm{~dB} \mathrm{SPL} \\
L I=59 \mathrm{~dB} S P L, L 2=50 \mathrm{~dB} S P L \\
L I=6 I \mathrm{~dB} S P L, L 2=55 \mathrm{~dB} S P L \\
L I=65 \mathrm{~dB} \mathrm{SPL}, L 2=45 \mathrm{~dB} \mathrm{SPL}\end{array}$ \\
\hline \multirow[t]{2}{*}{14} & Medline & Santos etal.( (17) & $2007 /$ SA & TEOAE & $80 \mathrm{~dB}$ \\
\hline & & & & DPOAE & $\mathrm{LI}=65 \mathrm{~dB} \mathrm{HL}, \mathrm{L} 2=55 \mathrm{~dB} \mathrm{HL}$ \\
\hline \multirow[t]{2}{*}{15} & Medline & Sisto et al. (26) & 2007/USA & TEOAE & $80 \mathrm{~dB}$ click \\
\hline & & & & DPOAE & $\begin{array}{l}L I=65 d B \& L 2=55 d B \\
L I=75 d B \& L 2=70 d B \\
L I=L 2=70 d B\end{array}$ \\
\hline 16 & Medline & Seixas et al. (19) & 2004/England & DPOAE & $\begin{array}{l}L I=65 \mathrm{~dB} S P L \& L 2=55 \mathrm{~dB} \mathrm{SPL} \\
\text { Also registered regarding rising stimulus level } \\
(\mathrm{LI}=35-80 \mathrm{~dB} \text { SPL in steps of } 5 \mathrm{~dB} ; L 2=L I-10)\end{array}$ \\
\hline 17 & Medline & Seixas et al. (20) & 2005/England & DPOAE & $\begin{array}{l}L I=65 \mathrm{~dB} S P L, L 2=55 \mathrm{~dB} S P L \text { Also registered } \\
\text { regarding rising stimulus level }(L I=35-80 \mathrm{dBSPL} \\
\text { in steps of } 5 \mathrm{~dB} ; \mathrm{L2}=\mathrm{LI}-10)\end{array}$ \\
\hline 18 & Medline & Job, Raynal, Kossowski (30) & 2007/Switzerland & DPOAE & $L I=65 d B, L 2=55 d B$ \\
\hline 19 & Medline & Balatsouras (27) & 2004/Poland & DPOAE & $\mathrm{LI}=\mathrm{L} 2=70 \mathrm{~dB} S P \mathrm{~L}$ \\
\hline
\end{tabular}

Legend: OAE, otoacoustic emissions; TEOAE, transient-evoked otoacoustic emissions; DPOAE, distortion product otoacoustic emissions; LI , L2, stimulus intensities; $\mathrm{dB}$ SPL and dB HL, decibels in sound pressure level. 
individuals evaluated was 3256, with 2246 males, 397 females, and 612 unspecified. The participation of males was greater than that of females, which reflects the overall lower number of women in the professional categories evaluated.

Regarding age, participants ranged from a minimum age of 14 years (22) to a maximum of 77 (18). In the variation of the EOAE findings, 1 study showed that the greater the subject's age, the greater the increase in tonal thresholds, while DPOAE thresholds decrease (19). In this study, which divided the subjects into 4 age groups (age, up to 20 years, 20-29 years, 3039 years, and over 40 years), it was observed that increasing age significantly influenced $(p>0.05)$ the amplitude of the EOAE.

In relation to the type of test chosen in the studies to investigate EOAE, of the 7 articles that are available in the national LILACS databases, 5 used DPOAE $(4,23,12,22,31)$ and only 2 used both tests $(15,16)$. Of the 12 international papers in the Medline database, 6 used DPOAE $(24,25,19,20,27,30)$ and 6 used both tests $(18,28,21,12,29,17,13,26)$.

It is suggested that DPOAE have characteristics that facilitate a more accurate diagnosis. For example, examiners can perform frequency and variation band analysis of responses depending on stimulus intensity (32). The examiner can vary the intensity, using the protocols L1 = $\mathrm{L} 2=70 \mathrm{~dB}$ SPL or $\mathrm{L} 1=65 \mathrm{~dB}$ SPL and $\mathrm{L} 2=55 \mathrm{~dB}$ SPL $(65 /$ 55 protocol).

As to the stimulus intensity, in the LILACS database, national articles varied intensities between L1 and L2, with the most frequently used intensity of L1 $=65 \mathrm{~dB}$ SPL and $\mathrm{L} 2=55 \mathrm{~dB}$ SPL $(12,15-17,20,22,26,28,30,31)$. In the Medline database, although the values L1 $=65 \mathrm{~dB}$ SPL and $\mathrm{L} 2=55 \mathrm{~dB}$ SPL were also used (26), there is a wide variation of stimulus intensities $(21,23,25-27,29)$.

Analysis of the DPOAE at different intensities of stimulation must be regarded very carefully, because it is likely that different mechanisms are responsible for the production of increasing or decreasing the sound intensity. Recent research indicates that the largest DPOAE amplitudes are obtained when L1 is more intense than L2 (L1 > L2) by up to $10 \mathrm{~dB}$ (33).

The lower intensity stimuli are more sensitive and accurate in the diagnosis of mild and moderate sensorineural hearing loss, which permits the variation of intensity to be used to differentiate degrees of mild and moderate hearing loss. That is, the $65 / 55$ protocol appears to be more sensitive in detecting mild hearing loss.
However, it is noteworthy that the proper adjustment of the probe is essential for recording otoacoustic emissions. As well as being sensitive to noise created by the environment or the patient himself, it is a highly sensitive procedure for disorders of the external ear and middle, thus generating possible false-positives (35). Moreover, the fact is indisputable that this procedure does not exclude the possibility of false-negative result, that is, integrity of cochlear physiology in auditory neuropathy.

In our review, only one study cited the possibility of false-positive and false-negative results, the causal factors that could have been calibration problems, noise level during the test and test-retest variability (29).

\section{FinAL COMMENTS}

In the universe that was analyzed, we observed that EOAE testing has been used effectively in the detection of cochlear changes and the early diagnosis of NIHL.

The literature reviewed publications that established results that can be considered as important parameters for subsequent applications of EOAE in workers exposed to noise.

We suggest that further epidemiological studies should be carried out to analyze the effectiveness of EOAE in workers exposed simultaneously to noise and other environmental contaminants (solvents, asphyxiants, metals, and pesticides), as well efforts towards suppression of the hazards in the occupational area.

\section{REFERENCES}

1. Gonçalves CGO. Análise do Programa de Apoio e Reabilitação para trabalhadores portadores de PAIR emuma metalúrgica. Distúrb Comun. 2007 abr [acesso em 2010 out 8]; 19 (1): 103-116. Disponível em: www.pucsp.br/ revistadisturbios/artigos/Artigo_512.pdf

\section{Pinotti KSA, Corazza MCA, Alcarás PAS. Avaliação} Eletrofisiológica do Nervo Auditivo em Pacientes Normoouvintes com Ausência do Reflexo Estapediano. Arq. Inter. Otorrinolaringol. [serial on the Internet]. 2009 [acesso em 2010 jun 08]; 13 (4):386-393. Disponível em: http:// w w w . a rquivos d e or l. org.br/ conteudo/ acervo_port.asp? $\mathrm{Id}=647$

3. Almeida SIC de, Albernaz PLM, Zaia P A, Xavier O G, Karazawa E H I. História natural da perda auditiva ocupacional provocada por ruído. Rev. Assoc. Med. Bras. 
[serial on the Internet]. 2000 June [acesso em 2010 jun 08]; 46 (2): 143-158. Disponível em: http://www.scielo.br/ scielo.php?script=sci_arttext \&pid=S010442302000000200009\&lng=en. doi: 10.1590/S010442302000000200009 .

4. Marques FP, Costa EA da. Exposição ao ruído ocupacional: alterações no exame de emissões otoacústicas. Rev. Bras. Otorrinolaringol. [serial on the Internet]. 2006 Jun [acesso em 2010 jun 08]; 72 (3): 362-366. Available from: http:// www.scielo.br/scielo.php?script=sci_arttext\&pid=S0034$72992006000300011 \& \operatorname{lng}=$ en. doi: 10.1590/S003472992006000300011.

5. Dunn DE. Cochlea morphology associated with overexposure to noise. Journal of the Ohio Speech and Hearing Associating. 1987:22-28.

6. Gonçalves CGO. O ruído, as alterações auditivas e o trabalho: estudos de casos em indústrias metalúrgicas em Piracicaba. [Tese de Doutorado em Saúde Coletiva]. Campinas: UNICAMP; 2003.

7. Oliveira JAA. Fisiologia clínica da audição - cóclea ativa. In: Nudelman AL (org.), Perda Auditiva Induzida pelo Ruído. Porto Alegre: Bagaggem, 1997, p. 101-142.

8. Brasil. Portaria №.19 de 9 de abril de 1998. Estabelecem diretrizes e parâmetros mínimos para avaliação e acompanhamento da audição dos trabalhadores expostos a níveis de pressão sonora elevados. NR 7 - Programa de Controle Médico de Saúde Ocupacional. Diário Oficial da União 30 dezembro de 1994. p. 21278.

9. Morata TC, Little MB. Suggested guidelines for studying the combined effects of occupational exposure to noise and chemicals on hearing. Noise and Health 2002; 4 (14): $73-87$.

10. Pialarissi PR, Gattaz G. Emissões Otoacústicas: Conceitos Básicos e Aplicações Clínicas. Internat. Arch. of Otorhinolaringol. [serial on the internet] 1997 [acesso em 2010 abr 22]; Vol1. Num2. 13p. Available from: http:// www.arquivosdeorl.org.br/conteudo/ acervo_port.asp?id=13

11. Lazmar A. Diagnóstico da doença profissional induzida pelo ruído. In: Nudelmann AA et al (Org.) Perda Auditiva Induzida pelo Ruído. Porto Alegre: Bagagem Comunicações, 1997, p.153-162.

12. Guida HL, Morini RG, Cardoso ACV. Avaliação Audiológica e de Emissões Otoacústicas em Indivíduos Expostos a Ruído e Praguicidas. Arq. Int. Otorrinolaringol. [internet]. 2009 [acesso em 2010 jun 08]; 13 (3):264-269.
Available from: http://www.arquivosdeorl.org.br/conteudo/ acervo_port.asp?id=626

13. Probst R, Harris FP, Hauser R. Clinical monitoring using otoacoustic emissions. British Journal of Audiology.1993, 27:85-90.

14. Souza DV de, Frota SMMC. Estudo Comparativo das Emissões Otoacústicas Evocadas em Militares Expostos e não Expostos ao Ruído. [Dissertação de Mestrado Profissionalizando em Fonoaudiologia]. Rio de Janeiro: Universidade Veiga de Almeida; 2009. 107p. [acesso em 2010 abr 22].

15. Amorim RB, Lopes AC, Santos KTP dos, Melo ADP, Lauris JRP. Alterações Auditivas da Exposição Ocupacional em Músicos. Arq. Int.Otorrinolaringol. [internet]. 2008 [acesso em 2010 jun 08]; Available from: http:// www.arquivosdeorl.org.br/ conteudo/ acervo_port.asp?id=544

16. Maia JRF, Russo ICP. Estudo da audição de músicos de rock and roll. Pró-Fono R. Atual. Cient. [online]. 2008, vol. 20, n.1 [acesso em 2010 jun 08]; pp. 49-54.

17. Santos L, Morata TC, Jacob LC, Albizu E, Marques JM, Paini M. Music exposure and audiological findings in Brazilian disc jockeys (DJs). Int J Audiol. 2007 May; 46 (5): 223-31.

18. Paini MC, Morata TC, Corteletti LJ, Albizu E, Marques JM, Santos L. Audiological findings among workers from Brazilian small-scale fisheries. Ear Hear. 2009 Feb;30 (1):8-15.

19. Seixas NS, Kujawa SG, Norton S, Sheppard L, Neitzel R, Slee A. Predictos of hearin threshold levels and distotion product otoacoustic emissions among noise exposed young adults) Occup Environ Med. 2004; 61:899-907.

20. Seixas NS, Goldman B, Sheppard L, Neitzel R, Norton S, Kujawa SG. Prospective noise induced changes to hearing amog construction industry apprentices. Occup Environ Med. 2005; 62:309-317.

21. Bockstael A, Keppler H, Dhooge I, D'haenens W, Maes L, Philips B, Vinck B. Effectiveness of hearing protector devices in impulse noise verified with transiently evoked and distortion product otoacoustic emissions. Int J Audiol; 47 (3): 119-33, 2008 Mar.

22. Fiorini AC, Parrado-Moran MES. Emissões otoacústicas produto de distorção: estudo de diferentes relações de níveis sonoros no teste em indivíduos com e sem perdas auditivas. Rev. Distúrb. Comun;17 (3):385-396, dez. 2005.

23. Alvarenga KF, et al. Emissões otoacústicas - produto de 
distorção em indivíduos expostos a o chumbo e ao ruído.Rev. Bras. Otorrinolaringol.[online]. 2003, vol.69, n.5, pp. 681686. ISSN 0034-7299. doi: 10.1590/S003472992003000500014 .

24. JohnsonAC, MorataTC, Lindblad AC, Nylen PR, Svensson EB, Krieg E, et al. Audiological findings in workers exposed to styrene alone or in concert with noise. Noise Health; 8 (30): 45-57, 2006 Jan-Mar.

25. Korres GS, Balatsouras DG, Tzagaroulakis A, Kandiloros D, Ferekidou E, Korres S. Distortion product otoacoustic emissions in an industrial setting. Noise Health; 11 (43): 103-10, 2009 Apr-Jun.

26. Sisto R, Chelotti S, Moriconi L, Pellegrini S, Citroni A, Monechi $\mathrm{V}$, et al. Otoacoustic emission sensitivity to low levels of noise-induced hearing loss. J Acoust Soc Am.2007 Jul; 122 (1): 387-401.

27. Balatsouras DG. The evaluation of noise-induced hearing loss with distortion product otoacoustic emissions. Med Sci Monit. 2004 May; 10 (5): CR218-22.

28. Prasher D, Al-Hajjaj H, Aylott S, Aksentijevic A.Effect of exposure to a mixture of solvents and noise on hearing and balance in aircraft maintenance workers. Noise Health; 7 (29): 31-9, 2005 Oct-Dec.

29. Lapsley Miller JA, Marshall L, Heller LM, Hughes LM. Low-level otoacoustic emissions may predict susceptibility to noise-induced hearing loss. J Acoust Soc Am. 2006 Jul; 120 (1): 280-96.
30. Job A, Raynal M, Kossowski M. Susceptibility to tinnitus revealed at $2 \mathrm{kHz}$ range by bilateral lowerDPOAEs in normal hearing subjects with noise exposure. AudiolNeurootol.2007; 12 (3): 137-44.

31. Parrado-Marron MES, e Fiorini AC. Aplicações clínicas das emissões otoacústicas-produto de distorção. Distúrb. Comun;14 (2):237-261, jun. 2003.32.

32. Lacerda ABM, Morata TC. O risco de perda auditiva decorrente da exposição ao ruído associada a agentes químicos. In: Morata, TC, Zucki F. (Org). Saúde Auditiva Avaliação de Riscos e Prevenção. São Paulo: Plexus, 2010, 99-117.

33. Kos MI, Almeida K de, Frota S, Hohino ACH. Emissões otoacústicas produto de distorção em normo ouvintes e em perdas auditivas neurossensoriais leve e moderada com os protocolos 65/55 dB NPS E 70/70 dB NPS.Rev. CEFAC [online]. 2009, vol.11, n.3, pp. 465-472. ISSN 1516-1846. doi: 10.1590/S1516-18462009000300014.

34. Souza LCA, Piza MRT, Alvarenga KF, Coser PL. Eletrofisiologia da audição eemissões otoacústicas: princípios e aplicações clínicas. São Paulo: Tecmedd, 2008. p.122123.

35. Durante AS. Emissões Otoacústicas. In: Fernandes FDM, Mendes BCA, Navas ALPGP. (Org). Tratado de Fonoaudiologia. 2 ed. São Paulo: Roca, 2009, 79. ISBN: 97885-7241-828-7. 